\title{
Zimbabwe: \\ The Ethnicisation of Zanu and the Downfall of Ndabaningi Sithole (1963-2000)
}

\author{
Owen MANGIZA \\ Ishmael MAZAMBANI
}

\begin{abstract}
This article is an exposition of the transformation of ZANU from being, primarily, a nationalist movement into an ethnic oriented party. Since its formation in 1963, ZANU was gripped by ethnicity, resulting in factions and contestations developing among party members. These contestations developed into open conflicts along tribal lines. The paper argues that ethnicity was so acute among ZANU party members to an extent that divisions were clearly drawn along the Shona sub-ethnic groups of Manyika (easterners), Karanga (southerners), and Zezuru (northerners). The competition for leadership positions and the fighting among members of these ethnic groups resulted in the death of some members of the party and the expulsion of others from the party. It is argued in the article that the persecution of Ndabaningi Sithole and his fallout as the ZANU president was a result of the ethnicisation of ZANU and the liberation strug-

Owen MANGIZA

Department of History

and International Studies,

Midlands State University, Zimbabwe

E-mail: omangiza@gmail.com

Ishmael MAZAMBANI

Department of History

and International Studies,

Midlands State University, Zimbabwe

E-mail: ishmazambani@gmail.com

Conflict Studies Quarterly

Issue 35, April 2021, pp. 37-50

DOI: $10.24193 / \mathrm{csq} .35 .3$

Published First Online: 05 April /2021

gle. The removal of Sithole as the party president and his replacement by Robert Mugabe exhibits these contestations among the Zezuru, Karanga and Manyika ethnic groups. We argue that the deposition of Sithole from ZANU in 1975 and his castigation as a "sell-out" and "tribalist" was a ploy by Robert Mugabe and other ZANU leaders to get rid of him and to replace him along ethnic grounds. The ethnic card was deployed to serve selfish political interests. It is these ethnic contestations and fighting which also brewed conflict and enmity between Mugabe in particular and Ndabaningi Sithole, among other factors. This hatred was clearly displayed later in the struggle for supremacy between Sithole's new party, ZANU-Ndonga and Robert Mugabe's ZANU-PF. It is stressed in the article that this enmity also culminated in the denial of a hero status to Sithole when he died in 2000. We also
\end{abstract}


argue that the deposition of Sithole from ZANU is one of the reasons why the Ndau people of Chipinge always voted for him and not Robert Mugabe in elections.

Keywords: Zimbabwe, Ethnicisation, Downfall, Contestations, ZANU, Hero status.

\section{Introduction}

The period of the liberation struggle in Zimbabwe, the 1960s and 1970s, witnessed the development of ethnicity, which on the one hand, affected the relations of the major political parties, ZANU and ZAPU, while on the other hand it affected the relations of members of these parties. This led to the split between ZAPU and ZANU in 1962 and serious conflicts and fights between members of the two political parties, especially in the urban areas of Salisbury and Bulawayo (Muzondidya \& Ndlovu-Gatsheni, 2008). In its worst manifestation during Zimbabwe's liberation struggle, ethnicity seriously affected Zimbabwe African National Union (ZANU), leading to the death of some members of the party and the expulsion of others. Herbert Chitepo's assassination has been linked to conflicts and contestations for leadership positions in ZANU. Such conflicts had fully evolved along tribal lines among the three major ethnic groups, the karanga, zezuru and manyika. Some members of ZANU also lost their leadership positions due to the ethnicisation of ZANU. Ndabaningi Sithole became a victim as he lost his presidency to Robert Mugabe in very unclear circumstances. Such prejudiced treatment of Sithole impelled him to form another party, ZANU Ndonga, with a strong support base among his own Ndau tribe. The overwhelming support which Sithole and ZANU Ndonga received from the people of Chipinge resulted in him becoming a major opposition force to ZANU-PF and Robert Mugabe since Zimbabwe's attainment of independence in 1980 until Sithole's death in 2000. The Ndau people's vote was an indignant one since they did not understand why their tribesman lost the ZANU presidency (personal communication, 2018, May 26). Not only did Sithole lose the ZANU presidency, but he also lost the hero status due to the spill over of the ethnic squabbles from ZANU to ZANU-PF.

\section{Ethnicity in Zimbabwe's Liberation War Politics}

The history of ethnicity in ZANU cannot be fully explained and understood without going back to the period of Zimbabwe's liberation struggle in the 1960s and 1970s. The ethnicisation of ZANU should be understood in the light of the ethnic dissensions of the 1960s and 1970s in the competing political parties. The in fights in Zimbabwe African People's Union (ZAPU) in the 1960s and the formation of Zimbabwe African National Union (ZANU) in 1963 climaxed into a series of conflicts that took an ethnic disposition (Sibanda, 2005). Parlous divisions and suspicions along tribal lines became deeply engraved in the minds of both ZAPU and ZANU leaders and their supporters 
from that period forth. Such ethnic divisions had to follow the political movements like a ghost for the whole period of Zimbabwe's liberation struggle (Shamuyarira, 1989).

However, besides ethnicity, there could be other reasons for the tensions and contestations between the two political movements, for instance, the difference in ideology and later on the granting of special treatment to ZAPU by the Soviet Union in 1969 . This treatment of ZAPU by the Soviet Union left ZANU in a delicate situation with the only option being that of seeking support from China (Shamuyarira, 1989). While this development served to polarise the relations between ZAPU and ZANU leaders and that of their followers, it only worsened relations that were already edgy. Ethnicity remains central to the whole drama of the divisions and polarisation which unfolded between the two political parties and their supporters during Zimbabwe's liberation struggle.

In 1963, ethnicity seized ZAPU members resulting in the fragmentation of the party. A core group of the Shona speaking members of the party, who included Ndabaningi Sithole, Robert Mugabe, Herbert Chitepo, among others, revolted against the leadership of the Ndebele-speaking Joshua Nkomo and founded a new political party; Zimbabwe African Natonal Union (ZANU) (Sithole, 1999). The breakaway ZANU members explained the causes of the split between ZAPU and ZANU as a lack of confidence in Joshua Nkomo's leadership. They indicated the differences they said existed between them and Joshua Nkomo. They argued that they differed with Nkomo in their war strategies, for they said they supported a policy of carrying out the struggle from within Southern Rhodesia rather than depending on international support. However the perceived difference in war strategies with Nkomo has been proven untrue, for ZANU's strategies were said to be similar to those of ZAPU. Joshua Nkomo echoed the similar strategies when he pronounced that ZANU "plagiarised its mother party (ZAPU) strategies and goals" (Sibanda, 2005). This he uttered from the fact that both parties had great faith in the fairness of the courts to decide their interests. They both engaged in foreign diplomatic relations to secure international support which ZANU had denied. Like ZAPU members, ZANU members went to foreign lands, for instance, Zambia, when their party was banned by the Smith regime (Sibanda, 2005).

However, the most convincing explanation in the member's rejection of Joshua Nkomo and the subsequent breakaway from ZAPU is the ethnic differences among ZAPU members before the break away. Ehnicity manifested itself through the conflicts that existed between the Ndebele and the Shona. Such ethnic tensions then continued to haunt the two political movements which comprised the two groups, showing its ugly face through the 1980s when Zimbabwe had already attained independence. The Gukurahundi massacres of the early 1980s were indeed a perpetuation of the ethnic conflicts of the 1960s and 1970s between the Shona and the Ndebele. From the 1960s onwards, therefore, ZANU was already an ethnic centred movement (Sibanda. 2005). 
The ZAPU-ZANU split of the 1960s also resulted in factions, ethnic fights and violence in the urban areas, a situation which sharply took an ethnic dimension in Zimbabwe's political developments (Muzondidya \& Ndlovu-Gatsheni, 2008). From this period onwards, the struggle for national independence was dominated by ZAPU on the one hand, which comprised the Ndebele and the Kalanga speaking people and Joshua Nkomo as the president, and ZANU on the other hand, comprising Shona speaking people, with Ndabaningi Sithole as the president-(Muzondidya \& Ndlovu-Gathseni, 2008). These political developments are a mirror of the political history of Zimbabwe from that period onwards. Ethnicity continued to dominate both ZAPU and ZANU. This ethnic division resulted in the political leadership accusing and counter accusing each other of tribalism as was the case of Ndabaningi Sithole and his group who accused Joshua Nkomo of tribalism and regionalism, as one of the justifications for breaking way from ZAPU (Sithole, 1998). As a result of these divisions, and as highlighted earlier on, ZAPU came to be known as the Ndebele people's party while ZANU was increasingly viewed as the party of the Shona people since they provided the party's widest support base (Masendeke, 1996). This ethnic factor became a permanent identity through to the time of Zimbabwe's attainment of independence in 1980. Thus, the ethnicisation of ZANU started manifesting itself when a group of Shona members of ZAPU broke away from the party to form ZANU in 1962.

As already indicated, ethnicity started to affect ZANU from the party's embryonic stage. Since its formation in 1963, ZANU was greatly affected by ethnic contestations and conflicts which were mainly among the Shona sub-ethnic groups of Manyika (easterners), Karanga (southerners), and Zezuru (northerners). At first throughout the 1960s and 1970s, ZANU, like ZAPU tried to deal with the issue of ethnicity, especially in party representations. The party tried to strike a balance in its leadership by having leaders drawn from the three dominant Shona groups mentioned earlier on, but this was short lived (Muzondidya \& Ndlovu- Gatsheni, 2008). This resulted in the party comprising such members as Ndabaningi Sithole (Manyika), Herbert Chitepo (Manyika), Robert Mugabe (Zezuru), among others. Even the central committee of the party tried to maintain a balance in its representation especially after its 1964 congress. Elected ZANU central Committee had the following tribal and regional composition; Manyika 8 members, Karanga 8 members, Zezuru 4 members and Ndebele 1 member (Sithole, 1999). This was also the case with ZANU's war council (Dare rechimurenga) formed in 1965. The council was tribally and regionally composed as follows: Manyika 4 members, Karanga 3 members, Zezuru 1 member (Sithole, 1999). However, despite the efforts to balance its membership, ethnicity continued to follow the party as it did when some party members broke away from the Nkomo led ZAPU, resulting in grave hatred and suspicion as shall be shown later in this chapter. Part of the problem was the failure by party members to develop mechanisms to deal with ethnic differences. The leadership 
condemned ethnicity during the day but used it by night as a political weapon which aided them in their power battles (Sithole, 1999).

The ethnicisation of ZANU became a permanent feature of the party even when it transformed into ZANU PF later. In the period after the formation of the ZANU war council, the ZANU leadership in exile saw the need to hold periodic council elections as a way to keep the party revived. While the 1964 council elections tried to maintain a balance of power, subsequent years witnessed a gradual change in this trend. Election results reflected the disappearance of some tribes from representation in the council. The 1973 war council election results, for instance, were as follows; Karanga 5 members, Manyika 3 members, Zezuru 0 members and Ndebele 0 members (Sithole, 1999). This is a true reflection of no other factor, but ethnicity at work. The ethnicisation of ZANU led to the vanishing of the Zezuru and the Ndebele from the war council. By the end of March 1975, the ethnic and regional composition of the war council was as follows; Karanga 5 members, Manyika 0 members, Zezuru 0 members and Ndebele 0 members (Sithole, 1999). This astonishing disappearance of some ethnic groups from the leadership positions in the war council makes one to think that the move to hold periodic council executive elections was a strategy by the dominant tribes to eradicate "weaker" tribes. Although the Zezuru left and joined FROLIZI in 1971, this was another split which obviously could not have occurred without dissatisfaction. This again was a result of ethnic tensions in the party. In ZANU at home, the party executive was dominated by the Shona. There was only one Ndebele, Enos Nkala, which again is another affirmation of how acute ethnicity was in the party (Sibanda, 2005).

In other incidences of an ethnic nature, in January 1975, a Manyika member of the war council, John Mataure was executed for participating in the Nhari rebellion of NovemberDecember 1974. In 1975 a Manyika member of the war council, Noel Mukono was expelled from the party for alleged counter revolutionary activities (Sibanda, 2005). It is interesting to note that such killings and expulsions were between the Manyika and Karanga dominant groups in the war council in exile in 1973. Such conflicts could not have been triggered by anything else, but a strong desire for leadership positions, with the Karanga planning to dominate and eradicate the Manyika. Ethnic differences propelled either of the two tribes to clamour for power and to outdo each other. These executions and expulsions are an exhibition of the ethnicisation of ZANU in its worst outlook. The ethnicisation of ZANU is also singled out for the death of the party's first ZANU chairman, Herbert Chitepo on 8 March 1975. There have been accusations and counter accusations as to who assassinated Chitepo, but the factor of ethnicity has not been doubted for influencing that assassination. Front line states presidents Kenneth Kaunda, Julius Nyerere, and Samora Machel held the view that Chitepo was a victim of the in fights in ZANU. In his conversation with Ndabaningi Sithole, Samora Machel stressed that "the revolution eats its own children" (Sibanda, 2005). 
Chitepo, who was still Chairman of the party at his death, was a victim of the ethnicisation of ZANU which brought about the fights between the two major groups, the Karanga and Manyika, as already indicated earlier. The pro-Sithole group also shared the above view concerning Chitepo's death when they maintained that ZANU was responsible for the death of Chitepo. Ethnic contestations were also revealed on the death of Chitepo when the pro Mugabe dare group argued, contrary, that it was imperialism and its agents that were responsible for ZANU's problems (Sibanda, 2005). Such differences in the way they perceived the circumstances leading to Chitepo's death clearly shows how deeply engraved ethnicity was in the ZANU leadership. In his lengthy letter to Zimbabweans, Ndabaningi Sithole argued that by 1974 ZANU had been infested by tribalism and regionalism which resulted in kidnappings and killings which affected people such as Chitepo (Sibanda, 2005). All this is a clear indication that ethnicity in ZANU had reached unprecedented levels.

\section{Sithole's Loss of the ZANU Presidency}

Squabbles that followed the death of Chitepo in ZANU among the leadership resulted in Sithole siding with other Manyikas in castigating the Chitepo's assassination. Accusations and counter accusations ensued after Chitepo's assassination, leading to complex relations evolving between Sithole's group and members pro to the war council, who were situated in Zambia. As a result of these ethnic tensions some members of the war council openly revolted against Sithole's leadership, preferring instead, that of Robert Mugabe through the Magagao declaration of 1975.The declaration saw the elevation of the zezuru ehnic group in which Mugabe belonged. Through the declaration, Sithole was viewed as a hopeless and ineffective leader of the revolution, a stance which greatly contributed to his downfall (The Patriot, January 9, 2014). As a result of these differences Ndabaningi Sithole was therefore labelled a "tribalist" and "regionalist," for all the regionalists were thought to be from eastern Zimbabwe (Manicaland), which is Sithole's home area (Sibanda, 2005).

Sithole's adamancy in defence of Chitepo is seen when he indicated that he would not keep quiet about the assassination since he would be asked many questions from his constituency in Chipinge by Chitepo's family, his own children, and by the generality of the people concerning the killing. Sithole strongly felt that it was better for him to be castigated and labelled for speaking out against Chitepo's death than to remain silent about it (Sibanda, 2005). In other words, Sithole pledged to defend the position of the Manyika people than to support the Karanga. This again shows the high levels of the ethnic tensions between the Manyika and the Karanga.

Ndabaningi Sithole could not stand the ground, especially when allegations after allegations became his daily experience following Chitepo's assassination. Prior to Chitepo's assassination he was also blamed for the unfortunate situation that befell the detainees 
when they were locked up at Sikombela detention camp between 1965 and 1968. The detainees mourned their prison situation which they blamed on Sithole, the ZANU president. They argued that he misled them resulting in their long stay in detention (Sithole, 1999). Sithole was also viewed as an incapacitated leader who could not bring much benefit to ZANU considering that he came from a very small tribe-Ndau, and that he came from a very remote area of Chipinge. To the other ZANU leaders these two factors meant that Sithole's following was quite negligible to build enough support base for the party. After a comparison was made with the other ZANU leaders, it was concluded that Sithole could not make the party vibrant with such a small following. He was then compared with such leaders as Leopold Takawira, Robert Mugabe and others who were thought to have the needed leadership potential and a wider support base (Sithole, 1999). Such allegations against Sithole and all the castigations alike served to widen the gap between the two competing tribes. Such ethnic condemnations in particular later served to widen the ethnic differences between the Karanga and the Ndau tribe, where Sithole came from. Ndabaningi Sithole came to be convinced, and he confessed that a leadership crisis had hit ZANU (Sithole, 1999).

Part of Sithole's blame by other ZANU leaders was that he neglected the guerrillas in Zambia and Mozambique at a time when they needed his support. His failure to spend some time with the guerrillas when he rushed to attend to his sick daughter in America in 1975 was not taken lightly by other ZANU leaders. By that action, Sithole was viewed as a failure in leading the party, and as someone who did not have the guerrillas at heart (personal communication, 2018, May 26). As mentioned earlier, he was viewed as a sell out of the struggle, a label that coasted him the ZANU presidency. This plot to oust him has been regarded by many as a coup. The coup was planned while they were in prison with the intention of elevating Robert Mugabe to the position of the ZANU president (Moore, 2014, pp. 302-318). Thus, in a dramatic way not fully comprehended by Sithole and his supporters, Sithole lost the ZANU presidency to Robert Mugabe in 1975. This became one of the worst scenarios of the high levels of the ethnicisation of ZANU. This also reveals the levels of power struggles that existed among ZANU members at that time.

The coup, however, was received differently by various circles concerned about Zimbabwe's liberation struggle. The coup, which coasted Sithole of, not only the ZANU presidency, but central committee membership as well, was received as a blessing by the Smith regime who viewed Sithole as an enemy since he had declared war against them. The Smith regime accepted Robert Mugabe as the new leader of ZANU (Sithole, 1999). However, the front line states, which supported Zimbabwe's struggle for independence, did not support the coup for reasons known to them. Their disapproval of the deposition of Sithole is shown by their insistence that he was supposed to be reinstated as the ZANU president (personal communication, 2018, May 27). Sithole's 
supporters, who were mostly, people from Manicaland, and more specifically, the Ndau tribe in Chipinge, did not take Ndabaningi Sithole's deposition lightly.

Sithole's deposition actually marked a turning point in the relations between him together with his Ndau supporters, and Robert Mugabe and his ZANU, and ZAPU PF supporters later. In much clearer terms the new relationship was characterised by enemity, suspicion, and more power contestations between the two leaders (personal communication, 2018, May 26). Sithole himself obviously could not support Robert Mugabe's leadership and neither did he accept it. Signs of things not going on well between Robert Mugabe and Ndabaningi Sithole could be seen in the period following the coup. The strained relations were visible. The two leaders could no longer share the same platform in public spaces as they used to do before Sithole was dropped. Each man was now working for himself (Sithole, 1999). The supporters of the two leaders could also not hide their strained relations. The supporters clashed and fought each other over the Mugabe-Sithole controversy, and sometimes they fought using guns (Sithole, 1999).What this entailed was the defeat of the Manyika and victory of the Zezuru, which again, clearly exhibits how deeply engraved ethnicity was in ZANU. Thus, the enmity which was brewed during this period between Mugabe and Sithole was never cured until Ndabaningi Sithole's grave.

\section{Sithole and the Ndau's defiance}

Sithole, out of anger, in great dissatisfaction, and as a way to show his protest, formed another party-ZANU Ndonga. The party did not only become the product of the ethnicisation of ZANU, but the refusal by Sithole to be dropped from the political arena. Thus he ushered in a strong opposition party against Robert Mugabe and ZANU PF in independent Zimbabwe until his death in 2000. The downfall of Sithole as the ZANU president, therefore, gave birth to more ethnic contestations and differences. Sithole himself was not spared by this contagious ethnicisation of ZANU, for his new party, ZANU Ndonga, exhibited ethnic inclinations to the Ndau tribe. Thus, Ndabaningi Sithole seized to be a mere political leader but also became a tribal leader. The people of Chipinge, which is Ndabaningi Sithole's home area, became Sithole's widest support base. The Ndau people began to jealously support their fellow tribes' man in the political battlefield, partly on the grounds that Sithole's oust from the ZANU presidency was an unfair treatment of him. They failed, also, to come to terms with the fact that the oust meant that Sithole was denied the opportunity to rule the country, come independence (personal communication, 2018, May 26). This loss of political power by Sithole was also a betrayal of the Ndau people who had joined the liberation war, partly, to support their fellow tribesman. The denial of political power to Sithole was also a denial of political power to the Ndau people. Ethnicity, therefore, is a resource which, just like other political resources, is used by some politicians because they perceive it appropriate at particular times for particular objectives. The masses who are the lubricants of the political machine also 
calculate that they stand to benefit in one way or the other from "our leader", or "our son", or "our homeboy", or our tribesman in power (Sibanda, 2005).

Sithole's downfall from the ZANU presidency had a ripple of effects as reflected by the way the people of Chipinge voted in elections from 1980 until Sithole's death in 2000. As a way of displaying their dissatisfaction in Sithole's downfall, the Ndau people naturally developed a strong passion for Sithole and ZANU Ndonga to an extent that each time they casted their vote in elections, they voted for Ndabaningi Sithole and ZANU Ndonga against Robert Mugabe and ZANU PF. Considering the election results for all the elections held after Sithole's oust, one can conclude that the Ndau people casted a protest vote. It became a chorus during election times for the people of Chipinge to always say "pandongapo", meaning that everyone was supposed to go and vote for ZANU Ndonga and not for ZANU PF (personal communication, 2018, May 26). In the elections conducted in Zimbabwe after Sithole's death in 2000, the people of Chipinge continued to cast an "angry" vote. They never voted for ZANU PF, and instead voted for the opposition Movement for Democratic Change (MDC) of Morgan Tsvangirai. The Ndau people viewed the MDC as a better "devil" than ZANU PF, which was their political and electoral rivalry since 1980. It was therefore clear among the Ndau people that an enemy of an enemy automatically becomes a friend as they did with the MDC. Thus, ZANU PF and its leader, Robert Mugabe, were never forgiven for Ndabaningi Sithole's loss of power in the 1970s.

Bad blood between ZANU-PF and ZANU-Ndonga was also reflected in the failure of the introduction of a one party state by ZANU PF and their Leader, Robert Mugabe. The introduction of a one party state was one of the major aims of Robert Mugabe and ZANU PF since 1980. They wanted to make ZANU PF the sole political party to which all Zimbabweans could lend their membership and support (Laakso, 2002). The existence of ZANU-Ndonga and other opposition political parties such as Zimbabwe Unity Movement (ZUM) of Edgar Tekere, therefore, hampered such a political development. The existence of many political parties, in a way, saved the people of Zimbabwe from being forced from being members of a single party, ZANU PF, and from voting for that single party in elections.

The need to establish a one party state by ZANU PF became one of the serious challenges facing ZANU Ndonga and other opposition parties in Zimbabwe's electoral history; especially in the 1990 general elections. This is mainly because the theme of that election was the possibility of introducing the challenged one party state. This made Manicaland, mostly, a hot bed of electoral politics since the ruling ZANU PF party had to contend with the supporters of Rev. Ndabaningi Sithole and those of Edgar Tekere. The lack of enough political space for such small political parties to participate in the run up to the1990 elections resulted in the opposition parties resorting to holding smallscale meetings rather than rallies. Political meetings were often held in private homes 
and were rarely announced publicly for fear of persecution (Moyo, 1992). However; this did not deter the Ndau people from voting for ZANU Ndonga against ZANU Pf. So Sithole and other opposition party leaders prevented ZANU PF and its leader, Robert Mugabe from establishing a one party state in Zimbabwe. This shows that the contestations for power between Sithole and Mugabe did not disappear with the attainment of independence in Zimbabwe. In fact their relationship became complex as it was now more of personal than political enmity. The fact that Sithole went into self imposed exile in the mid 1980s can clearly be explained, in Sithole's view that his life was in danger as a result of the political situation (personal communication, 2018, May 26, 2018).

\section{Ethnicity and Sithole's Denial of a Hero Status}

Ndabaningi Sithole's downfall was not only an experience of his loss of the ZANU presidency and membership of the ZANU central committee, but also his erasure from the political history of Zimbabwe. When he died in 2000 it came as a shock to many, and more so to members of his Ndau tribe that Ndabaningi Sithole was not accorded a hero status. Robert Mugabe and the ZANU PF government presented a cold shoulder on the matter. Their expression that they did not know Ndabaningi Sithole disturbed many who were following the political history of the country (personal communication, 2018, May 26, 2018). The implication of this denial of hero status to Sithole is that he had not made any significant contribution to the history of Zimbabwe, a situation which many, especially the Ndau people, embraced with grief. Ndabaningi Sithole was thus deliberately omitted from the political history of Zimbabwe and was "forgotten" by the ruling party and government. In fact this is one reason why Sithole has become an immortal figure among his tribesmen to this day. Thus, the denial of a Hero status sealed Sithole's fate in the political arena.

The label which he received from other political leaders in the 1970s, that of being a sell out and counter revolutionary, became a permanent mark affecting even his contribution to national history. Many still do not see any justification for his exclusion from the history of the country. On the contrary he is still perceived by many as having played a positive role in the nationalism drama. He is viewed as having conceived a vision of the Zimbabwe to be formed after the revolution, and this vision cannot simply be slipped under the carpet. Ndabaningi Sithole is reckoned by many, including his tribesmen, not as a sell out, but a veracious hero of the nation. Considering the role he played together with other known heroes, Sithole has therefore become an unsung hero of Zimbabwe's liberation struggle. His deliberate omission from Zimbabwe's national history is an indication of the strong ethnicisation, not only of ZANU, but also of ZANU PF. The other political leaders' view of Ndabaningi Sithole and his small Ndau tribe is that of a people whose contribution to national history is negligible.

The heroism of Ndabaningi Sithole is perceived by his supporters, even today, on the grounds that the formation of ZANU in 1963 was largely his brain child. He is viewed, not 
only as the founder of ZANU, but also its pioneer president (personal communication, 2018, May 27). Under his leadership, ZANU attracted great support from the majority of the people in the country during the struggle for independence from British rule. It is this resounding support ZANU received which made many people to join the liberation struggle. Ndabaningi Sithole is regarded as having laid a strong foundation on which the liberation struggle came to be built (personal communication, 2018, May 26, 2018). Sithole is also fully credited for exhibiting high qualities of bravery, not only in leading the party structures, but also in declaring war against Ian Smith and the Rhodesian Front. His full participation in the liberation struggle has left a lot to be desired from his supporters, but mostly his tribesmen (personal communication, 2018, May 27). Such a participation in the liberation struggle for Zimbabwe, as other nationalists did, makes him qualify to be called a hero of Zimbabwe's liberation struggle. During his leadership as the ZANU president Sithole also fully participated in the consultation of spirit mediums (masvikiro) whose contribution during Zimbabwe's liberation struggle was of immense magnitude (personal communication, 2018, May 26, 2018). The wooden rod "ndonga" in Ndau dialect, which Sithole is said to have possessed, was believed to have been ordained by the spirit mediums and was a guiding instrument in the struggle. It is asserted that whenever Sithole pointed to the Eastern direction (Mozambique) with the rod, people made a stampede crossing the border into Mozambique to participate in the war of liberation (personal communication, 2018, May 27). Even though he was not accorded a hero status, the nostalgia which his supporters have for him is strong since they believe that he left a legacy to be cherished.

Comparatively to the experience of most political leaders and heroes of the liberation war for Zimbabwe, Sithole also experienced a painful life in detention from 1964 to 1975. He is one person who suffered under the Smith regime in a bid to liberate the country from British colonial rule. Such an experience as a detainee and political prisoner has erased any room of doubt among many concerning his hero status. He is, thus, considered by many as a hero of Zimbabwe's liberation struggle. Sithole was not accorded a hero status as a result of the high levels of ethnicity that continued to grip ZANU PF and its leadership who viewed him as a non contributor to the liberation struggle. Also, when he returned to southern Rhodesia in 1977, after having been ousted from power as the ZANU president, Sithole did not give up nationalist politics. Instead, he formed a new organisation, the African National Council (ANC-Sithole) and at times known as ZANU Sithole, later renamed ZANU Ndonga. One of the aims of the new movement was to liberate the country from British colonial rule. Sithole's new internal politics emphasised an imagination of the liberated country. The new country was thought to be a multi racial democracy with a vibrant economy. Sithole demonstrated this through his political campaigns when he dispensed cars and other rewards to his followers. However, Ndabaningi Sithole failed to maintain his political fortunes in the 1970s for he was overshadowed by Abel Muzorewa in terms of majority support. His resilience, however, left a mark to reckon with. 
Sithole's commitment to the liberation struggle is seen from his writings which include African nationalism and Roots of the Revolution. These writings reveal a lot about his conception of the nationalist liberation struggle and his perception of an independent Zimbabwe. His contribution is also seen in his writing in defence of the widely condemned internal settlement in his work In Defence of the Rhodesia Constitutional agreement. In this work he stood firm in defence of the settlement which marked a transitional period from colonial rule to majority rule in Zimbabwe. Sithole's greatness is also seen from the liberation struggle when he went to China with some guerrillas to train in guerrilla warfare. It was from such trainings that recruitment for the liberation war began (personal communication, 2018, May 26). He began his recruitment among the people of Chipinge who became one of the first groups to cross into Mozambique under Sitholes leadership and guidance. His recruitment was also characterised by a strong education to the people about the oppressiveness of the colonial system. Sithole is one leader, among others, who is thought to have worked hard to stop such colonial policies as the reduction of the herds of cattle which Africans were allowed to keep in a bid to reduce overgrazing. Sithole enlightened the Ndau among other people of the fact that such a policy by the Europeans was enacted only to oppress them. It became clear therefore among many that the colonial masters did not want competition from Africans (personal communication, 2018, June 9).

Not only did Sithole contribute in the stoppage of the cattle policy, but also contributed in bringing to an end the slavery going on in Mozambique under Portuguese rule where by the people of Chipinge in particular were taken into Mozambique to labour in the cutting down of trees in order to prepare sisal. That was one of the most dreaded and detested colonial policies among the Ndau people as it led to great oppression and displacement of many people. The support and heroism ascribed to Sithole was partly due to the fact that he managed to put to an end such oppressive colonial policies (personal communication, 2018, June 9). The perception therefore that Sithole was a sell out of the Revolution is dismissed by these facts. When he died in 2000, his burial at his Freedom farm at Mount Selinda in Chipinge was a perpetuation of his downfall. The burial was conducted amidst immense grief and high emotions among Sithole's tribesmen, since he was not accorded the most awaited hero status.

However, members of his party, ZANU Ndonga believe that Sithole suffered a lack of recognition as a hero of the liberation struggle because of the nature of the politics of his days. His supporters foresee a time when history shall be revisited and corrections are made Sithole's supporters look up to a time when all heroes of Zimbabwe's liberation struggle shall be accorded their hero statuses without history being polluted by such negative forces as ethnicity and unnecessary power struggles (personal communication, 2018, May 26). 


\section{Conclusion}

The ethnicisation of ZANU can be traced back to the period of the 1960s and 1970s when Zimbabwe was under siege from the war of liberation. It is during this period that due to ethnic differences, among other factors, some ZAPU members decided to break away from the party to form ZANU. That marked the beginning of the separatism along ethnic lines between the Ndebele and the Shona. Thus, ZAPU and ZANU developed into like poles along ethnic lines with ZAPU being a Ndebele people's party while ZANU became a Shona people's party. The ethnicisation of ZANU, which has been discussed at length in this chapter evolved fully into hatred and suspicion among some members of the party. Friction developed among the karanga, zezuru, and manyika tribes as a result of the ethnic differences. These ethnic conflicts and differences resulted, in their worst manifestation, in the assassination of ZANU's first Chairman Herbert Chitepo in 1975, and the expulsion of some members from the party. Ndabaningi Sithole, as discussed above, was a victim of this ethnicisation of ZANU when he lost the ZANU presidency to Robert Mugabe in very unclear circumstances. It is such an unfair treatment of Sithole by other ZANU leaders which led to him forming ZANU Ndonga.

The existence of ZANU Ndonga, as noted earlier, displayed another form of ethnicity, for the Ndau people treated themselves as an entity in their support for Sithole and ZANU Ndonga. During elections, the people of Chipinge always voted for ZANU Ndonga and Ndabaningi Sithole against ZANU PF and Robert Mugabe. This they did for all the elections held before Sithole's death. Even when Sithole died, the Ndau people continued to cast a protest vote against Robert Mugabe and ZANU PF.

This became a major challenge for ZANU PF and Robert Mugabe, especially considering the fact that they failed to establish a one party state due to the opposition from ZANU Ndonga, among other parties. The ethnicisation of ZANU and later ZANU PF is seen from that party's denial of a hero status to Sithole when he died in 2000. This was partly because Sithole was neither a karanga nor a zezuru, the two politically dominant tribal groups. This was also worsened by the fact that Sithole came from a very small Ndau tribe and from a remote area of Chipinge, which made him not qualify to lead, as perceived by other ZANU leaders. As a result the Ndau people agitated with grief at Sithole's downfall. However, the Ndau people still perceive that their day shall come when history will be corrected. This they anticipate considering the fact that Ndabaningi Sithole was deliberately omitted from the history of Zimbabwe. He has become an unsung liberation war hero of Zimbabwe.

\section{References}

1. Laakso, L. (2002). When Elections are just a formality: Rural urban dynamics in the dorminant- party system in Zimbabwe. In M. Cowen and L. Laakso (Eds.), Multiparty Elections in Africa (pp. 325-345). James Currey. 
2. Masendeke, A. F. M. (1996). A materialist conception of ethnicity in Africa: Mozambique and Zimbabwe in comparative perspective. A Thesis submitted to the U.Z Department of Political and Administrative Studies, U.Z.

3. Moore, D. (2014). The Zimbabwe People's Army Moment in Zimbabwean history, 19751977: Mugabe's rise and democracy's demise. Journal of Contemporary African Studies, 32(3), 302-318. DOI: https://doi.org/10.1080/02589001.2014.956499.

4. Moyo, J. N. (1992). Voting for Democracy: A study of election politics in Zimbabwe. University of Zimbabwe Publications.

5. Muzondidya, J., \& Ndlovu-Gathseni, S. (2008). Echoing silences: Ethnicity in post-colonial Zimbabwe, 1980-2007. (2008). African Journal on Conflict Resolution, 7(2), 275-297. DOl: 10.4314/ajcr.v7i2.39418.

6. Shamuyarira, N. (1989). An overview of the struggle for unity and independence. In C. S. Banana, (Ed.), Turmoil and Tenacity: Zimbabwe 1890-1990. College Press.

7. Sibanda, E. M. (2005). The Zimbabwe African People's Union, 1961-1987: A political insurgency in Southern Rhodesia. African World Press.

8. Sithole, M. (1998). Managing ethnic conflicts in Zimbabwe in Nnoli, O. (Ed.), Ethnic Conflicts in Africa (pp. 360-379). Codesria Book Series.

9. Sithole, M. (1999). Zimbabwe: Struggles within the Struggle. Rujeko Publishers.

10. The Patriot (2014, January, 9). The Mgagao Declaration (Oct 1975). The Patriot. Retrieved from https://www.thepatriot.co.zw.old-posts. 